\title{
Genotype-phenotype correlation in XLHED: insights into the biology of ectodysplasin
}

\author{
KM Huttner $^{1 *}$, DK Grange ${ }^{2}$, OD Klein ${ }^{3}$, H Schneider $^{4}$ \\ From 5th International Conference on Ectodermal Dysplasia (ED2012) \\ Erlangen, Germany. 1-3 June 2012
}

X-linked hypohidrotic ectodermal dysplasia (XLHED) is the most common of the ectodermal dysplasias, with a classic presentation of hypodontia, hypohidrosis, hypotrichosis and secretory gland hypoplasia. Mutations in the ectodysplasin gene $(E D A)$ underlie XLHED with nearly 200 different mutations reported. $E D A$ encodes a type 2 transmembrane protein of the TNF family (EDAA1), the active form of which is released from the cell surface following furin proteolytic cleavage. During normal human development, EDA-A1 multimers bind to their cognate receptor (EDAR) driving maturation of ectodermal placodes into sweat ducts, hair follicles, tooth buds, and secretory glands. In the absence of functional EDA-A1, all of the above are compromised.

As genotype-phenotype correlations in XLHED have not yet been characterized satisfactory, natural history studies incorporating non-invasive, quantitative assessments were conducted on 120 genotyped XLHED males, age newborn to 60 years. This extensive cohort, representing 69 different mutations, can now be analyzed for phenotypic variation associated with alterations in the intracellular, transmembrane, extracellular pre-cleavage, furin recognition, collagen-like domain, and receptor binding regions of the EDA-A1 protein. Approximately 3/4 of the XLHED patients evaluated had missense or nonsense $E D A$ mutations and 1/4 had indel mutations. In an initial approach to genotype-phenotype correlation, the severe or "null" phenotype (anhidrosis), with absence of both sweat ducts and inducible sweating, was associated with 55 of the $E D A$ genotypes. The remaining 14 EDA mutations were associated with the presence of normal appearing but hypofunctional sweat ducts, highlighting specific regions of the EDA-A1 protein where non-termination mutations allowed for activation of sweat duct development but through aberrant pathways.

${ }^{1}$ Edimer Pharmaceuticals Inc, Cambridge, USA
These experiments of nature may provide novel insights into the biology of ectodysplasin biosynthesis and functional activation of the ectodysplasin/EDAR/NFkB pathway.

\section{Author details}

${ }^{1}$ Edimer Pharmaceuticals Inc, Cambridge, USA. ${ }^{2}$ Washington University, St Louis, USA. ${ }^{3}$ University of California, San Francisco, USA. ${ }^{4}$ University Hospital Erlangen, Germany.

Published: 25 May 2012

doi:10.1186/1746-160X-8-S1-P1

Cite this article as: Huttner et al:: Genotype-phenotype correlation in XLHED: insights into the biology of ectodysplasin. Head \& Face Medicine 2012 8(Suppl 1):P1.
Submit your next manuscript to BioMed Central and take full advantage of:

- Convenient online submission

- Thorough peer review

- No space constraints or color figure charges

- Immediate publication on acceptance

- Inclusion in PubMed, CAS, Scopus and Google Scholar

- Research which is freely available for redistribution
() Bïomed Central
Full list of author information is available at the end of the article

C Biomed Central

(c) 2012 Huttner et al; licensee BioMed Central Ltd. This is an Open Access article distributed under the terms of the Creative Commons Attribution License (http://creativecommons.org/licenses/by/2.0), which permits unrestricted use, distribution, and reproduction in any medium, provided the original work is properly cited. 